\title{
3D Modelling as a Tool for Landscape Restoration and Analysis
}

\author{
Jan Pacina, Kamil Novák, and Lukáš Weiss
}

\begin{abstract}
Department of Informatics and Geoinformatics, Faculty of the Environment, J. E. Purkyně University, Králova výšina 7, 400 96, Ústí nad Labem, Czech Republic \{Jan.Pacina, Kamil.Novak\}@ujep.cz, Weiss.Lukas@email.cz
\end{abstract}

\begin{abstract}
The region of North-west Bohemia has been influenced by the open cast mining for more than the last hundred years. During this period has the coal mining activity become very intense leaving huge change on the landscape. We may require the original landscape for many purposes (historical, landscape renewal). One of the ways how to reconstruct the original shape of the landscape is the usage of historical maps and old aerial photographs made in the period before the dramatic georelief changes. As the data sources, we use the maps of the $3^{\text {rd }}$ Military survey 1:25000 after reambulation, aerial photographs taken in years 1938, 1952, 1995 and maps of stabile cadaster. The reambulated maps contain clearly readable elevation data (contour lines), which were used for reconstructing the original landscape. From processed aerial photographs we get the Digital Surface Model of the coal mines in different time periods.
\end{abstract}

Keywords: georelief reconstruction, $3^{\text {rd }}$ Military survey, stabile cadaster maps, aerial photographs, digital surface model, volumetric analysis.

\section{Introduction}

The area between the towns Kadan̆ and Duchcov (North-west Bohemia, the Czech Republic) is a part of so called Black Triangle [3] with active coal mining activity. The Brown coal has been mined in this area for ages, but the mining has become very intense in the last 80 years. Brown coal is not located too deep in the coal basin, so the technology of open-cast mines is widely used in this area. The open-cast mining is a rather cheap technology of coal mining giving access to huge loads of brown coal, but with a destructive effect on the surrounding environment.

This region used to be focused on agriculture, with towns and little villages spread all over the basin. The coal mining followed by the heavy industry has changed the view and shape of this region a lot.

In this area there were 3 Hot Spots delineated- areas with landscape degraded by coal mining. Each of these Hot Spots has its significant structure, usage, problems and vision. Within Hot Spots there are the following areas (see Fig. 2):

- Jezeří castle - a historical castle built at the edge of Krušné hory (Ore Mountains). Currently endangered by geological instability and landslides. 
- Lake Most - an open-cast mine currently turned into a hydric recultivation (landrenewal). The town Most, destroyed in 1970', was originally settled in this area.

- Open-cast mine Bílina and dump Radovesice - one of the biggest active coal mines in the region.

The purpose of this paper is to show the possibilities of landscape restoration on these different Hot Spots using the technologies of GIS and 3D modeling. For this purposes we use the old maps of the region and historical aerial photographs, as these data sources are very relevant historical materials that could be used for this kind of task.

The landscape reconstruction requires elevation data from the period before the intensive coal mining activity and in some cases also data from different time periods.

This area has been closely mapped in 1930' thanks to its geographic location (which is close to the border with Germany) and the huge brown coal reserves. The maps of the $3^{\text {rd }}$ Military survey 1:25 000 of this region were reambulated in the period $1934-1938$ and in 1938 was the region covered with aerial photographs. The current state of the georelief within the coal mines cannot be easily obtained and the coal mining companies are not a well accessible data source at all. Here we have to use the aerial photographs for Digital Surface Model (DSM) and further on Digital Elevation Model (DTM) creation.

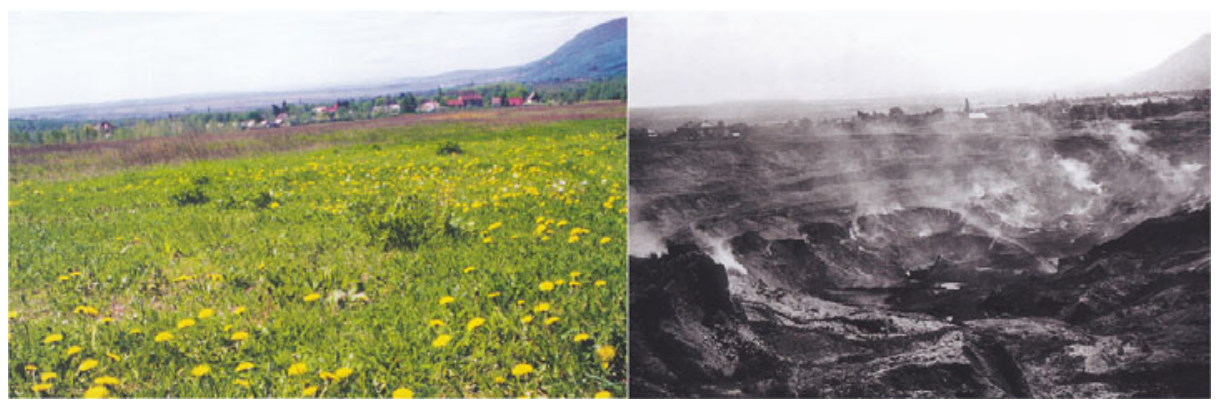

Fig. 1. Georelief change in the Basin of Most - 1960' and 2000 [11]

\section{Data and Methods}

In this paper we work with old maps and historical/current aerial photographs. Old maps used for this project are the maps of the $3^{\text {rd }}$ Military survey 1:25 000 after reambulation and Stabile cadaster maps. Historical aerial photographs originate from the years 1938, 1953, 1987 and the recent aerial photographs from the year 2008.

\subsection{Old Maps}

The maps of the $3^{\text {rd }}$ Military survey of this region were reambulated in 1930' apparently for the strategic purposes with upcoming of the $2^{\text {nd }}$ World War. Elevation data are clearly readable in these maps in the form of contour lines and elevation points. The contour line interval is varying from $20 \mathrm{~m}$ in flat areas to $2.5 \mathrm{~m}$ in hilly areas. These maps are in scale 1:25 000 and are the primary source of historical data. 
Other sources of historical maps are the Stabile cadaster maps 1:2880. These maps were created in the period $1826-1843$ and they are one of the most reliable sources for land-use development analysis.

All maps covering the Hot Spots have to be georeferenced. Spline transformation implemented in ArcGIS was used to georeference the data. The spline transformation is a true rubber sheeting method and is optimized for local accuracy but not global accuracy. It is based on a spline function - a piecewise polynomial that maintains continuity and smoothness between adjacent polynomials. [2]

The spline transformation was chosen as it fulfills the position accuracy of the transformed requested for the DTM creation in this project.

Approximately 150 to 250 identical points were chosen in each map sheet of the $3^{\text {rd }}$ Military survey (dependently on the input data) to secure the local accuracy. With respect to the map scale to a local accuracy were the Stabile cadaster maps georeferenced using approximately 30 identical points in each map sheet.

The transformation accuracy has been visually tested with the MapAnalyst application [5] by applying a regular square network on the transformed data.

Digitized contour lines are further on used for Digital Terrain Model (DTM) creation.

\subsection{Aerial Photographs}

All of the three Hot Spot areas are fully covered with aerial photographs from the years 1938, 1953, 1987 and 2008.

Aerial photographs have been processed in the standard way of photogrammetry using the Leica Photogrammetric Suite (for detail description of aerial image processing in this region, see [9] and [13]).

The historical images from the years 1938 and 1953 are not in a very good visual quality. The images are noisy, scratched, and affected by the contemporary technology of creation - this affects especially the selection of Ground Control Points (GCP's) and the automatic Digital Surface Model (DSM) creation from aerial images.

On the aerial images from the year 1938 and 1953 are within the Hot Spot areas large parts of the landcape that has changed a lot. The recent data are practically useless for processing the GCP's in these areas. Here were used partially the old maps $\left(3^{\text {rd }}\right.$ Military survey) to locate the object on the historical aerial photographs, recent orthophoto for the surrounding areas without a significant change and the orthophoto from 1953 accessible at http://kontaminace.cenia.cz for the other areas.

The following aerial images were used for the different Hot Spots:

- Jezeř́ Castle - years 1953 and 2008,

- Lake Most - years 1953 and 2008,

- Open-cast mine Bílina - years 1938, 1987 and 1995.

\subsection{DTM and DSM Creation}

Several DTM's and DSM's were created under processing of the Hot Spots. We require DTM as an input for aerial image processing for defining the GCP's elevation information. Here we use the ZABAGED® [1] contour lines and digitized contour lines from the maps of $3^{\text {rd }}$ Military survey. 


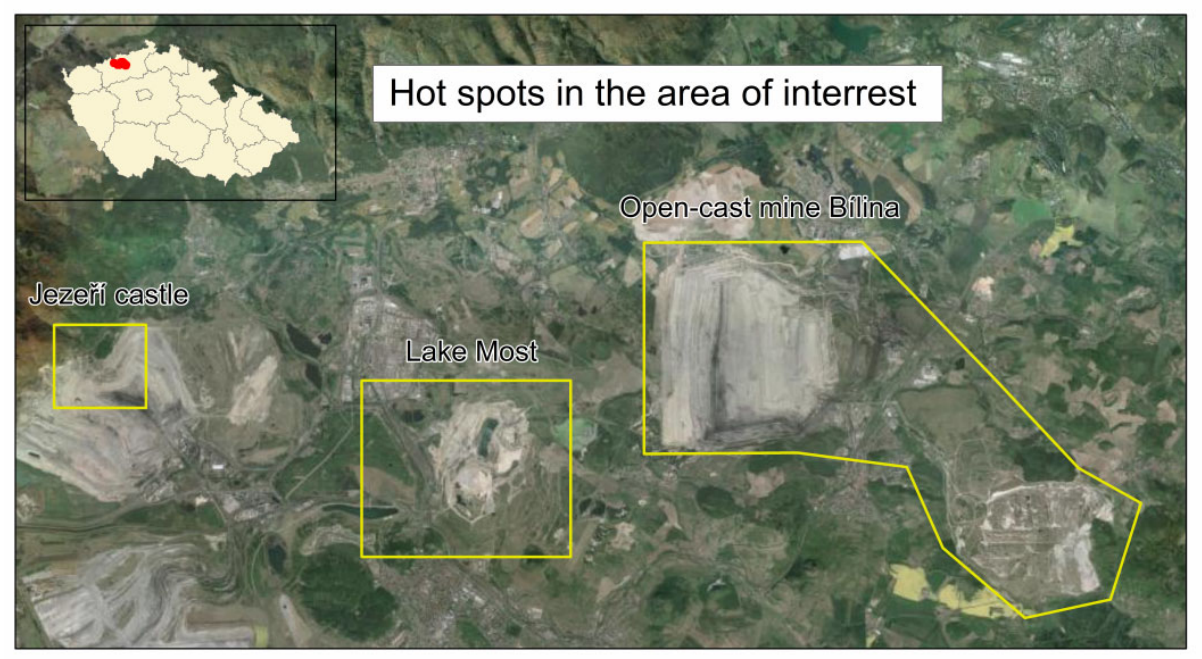

Fig. 2. Hot Spots overview

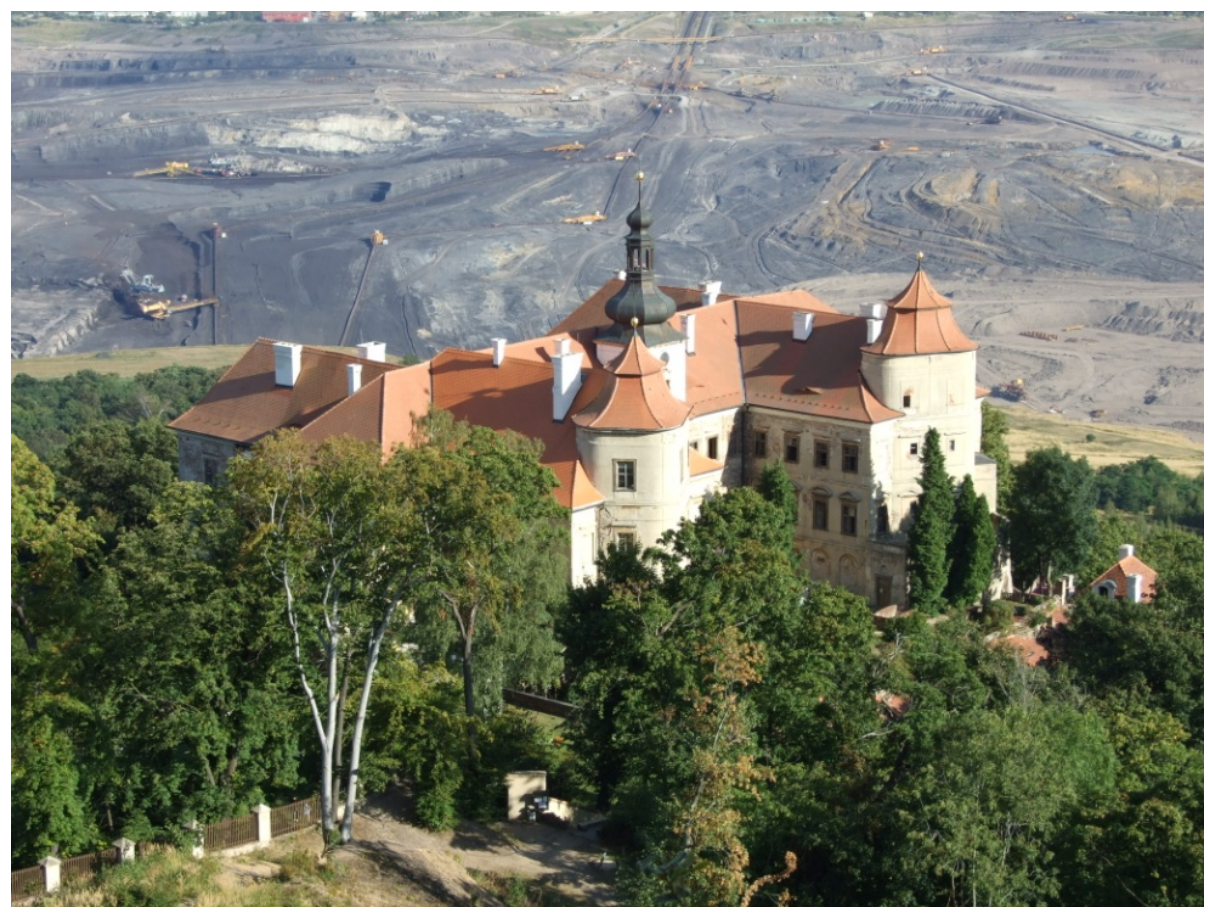

Fig. 3. Jezeří castle at the edge of a coal mine (author's photo) 
The DSM's are results of automatic image correlation. This method is used for automatic DSM extraction from aerial images with known orientation parameters with image overlap (in our case 60\%). The extracted DSM's are the desired results for historical landscape restoration.

The precise methodology for DTM and DTM creation is described in [9].

\subsection{Hot Spot Characterization}

All of the processed Hot Spots are presented on Fig. 2. In each of the Hot Spot is the research focused on different topic, requiring slightly different methodology.
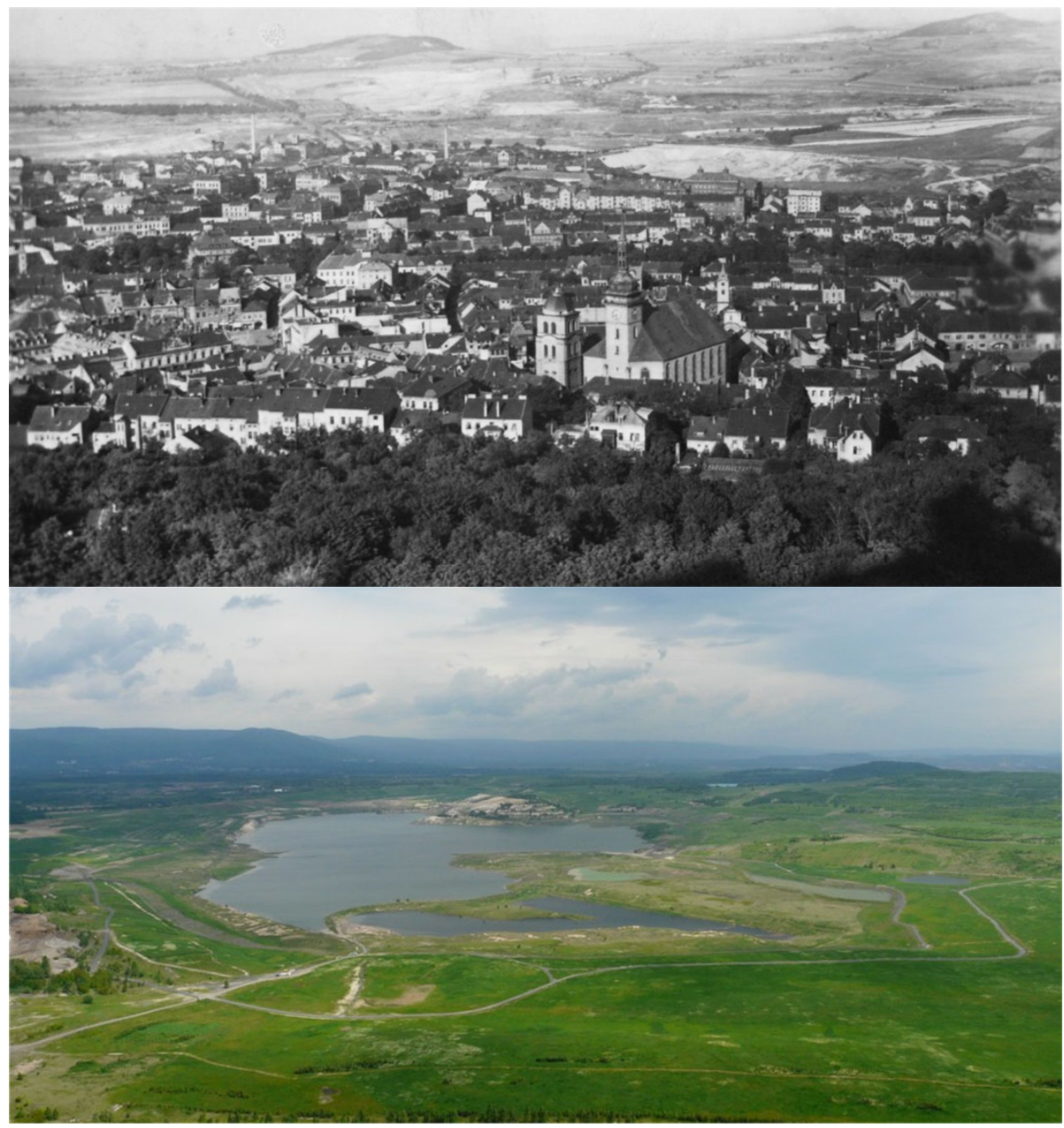

Fig. 4. The landscape change within the royal town Most [4] [10] 


\section{Jezeří Castle}

The castle Jezeři is one of the biggest castles in the Czech Republic, founded in the $14^{\text {th }}$ century. The castle is a part of the national cultural heritage, but it is highly endangered by the surrounding coal mines. The research in this Hot Spot is focused on the landscape and land-use development. The forest garden surrounding the castle and the castle itself are highly endangered by the surrounding coal mine and by landslides connected with the mining activity (see Fig. 3).

\section{Lake Most}

This Hot Spot is a significant example, how is the open-cast mining activity changing the landscape. Within this Hot Spot used to be the royal town Most, destructed in the 1970'. When the coal mine was depleted, it has been changed into a hydrical recultivation (over flooded mine) with future leisure time usage (see Fig. 4). Within this Hot Spot we focus on the georelief changes.

\section{The open-cast mine Bílina}

The open-cast mine Bílina is one of the largest active mines in the region. Several villages have been destroyed as the mine was spreading. In this Hot Spot, we focus on volumetric analysis - based on DTM'S and DSM's and we would like to summarize the whole amount of material that has been mined in the mine, or moved into the outer deposits.

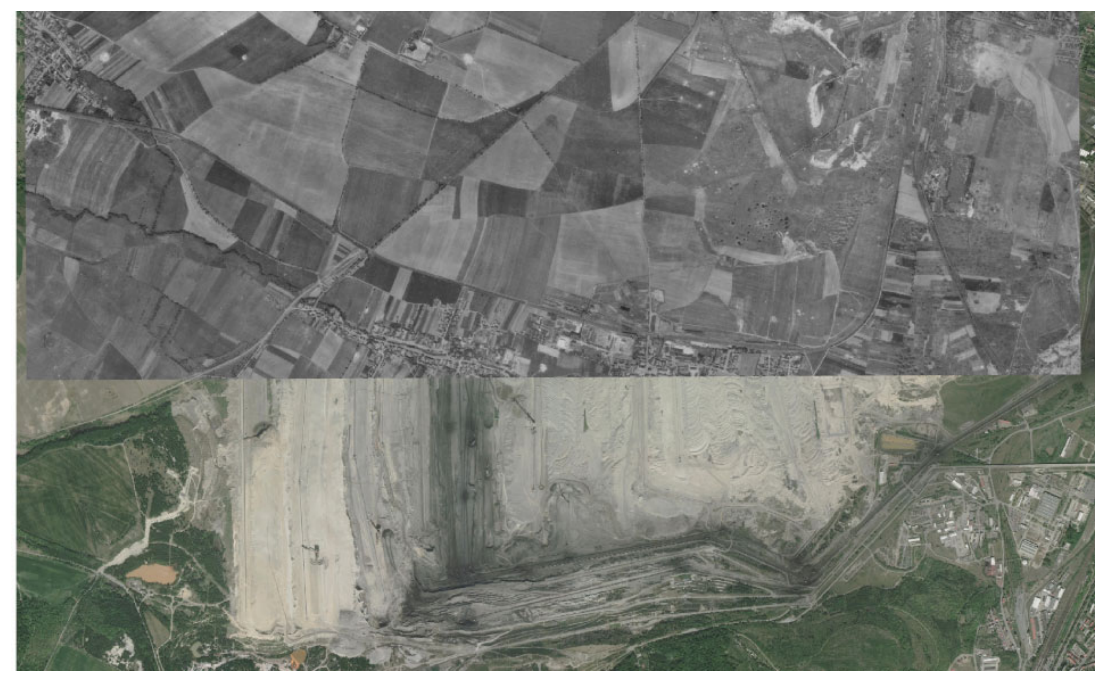

Fig. 5. Landscape change in the surroundings of town Bílina

The Hot Spot Bílina is the largest area processed in this paper, thus in this paper we focus only on the selected area representing the main coal mine and its surroundings, excluding the dump Radovesice. See Fig. 6. 


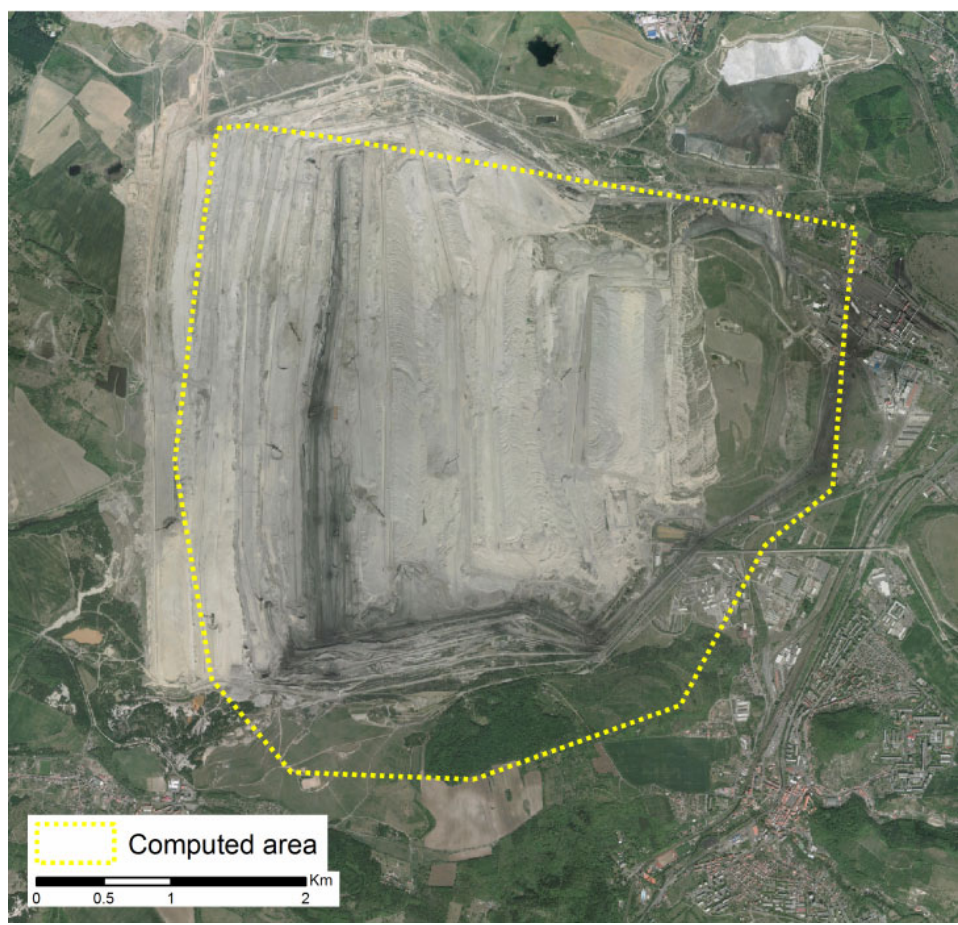

Fig. 6. The area for volumetric analysis within the open-cast mine Bílina

\section{Analysis}

The meaning of this project is to show the possible reconstruction works concerning the landscape restoration and the land-use analysis. Thus we focus on slightly different analysis in our investigation Hot Spots.

\subsection{Castle Jezeří Analysis}

The position of Jezerrí castle is on the very edge of the open-cast coal mine Československá armáda (Czechoslovak army). The coal mining activity, that has stopped at the very edge of the Ore Mountains is causing geological instability resulting in very huge landslides in the surrounding localities.

The castle should be protected from sliding into the coal mine by a pillar, situated under the castle. The pillar is also located in the forest garden. In the past years huge landslides appeared also in the pillar (see Fig. 7). One task of this land modeling issue would be to evaluate the landslides, the amount of material that has slide and the landslides position. 
This analysis requires very precise elevation data of this area, which are currently unreachable for public or scientific purposes, as they are the property of the coalmining company. In the year 2012 would be this whole area a part of the national photogrammetry survey. Results of this survey will be very precise photogrammetric digital imagery that will be used to finish the analysis.

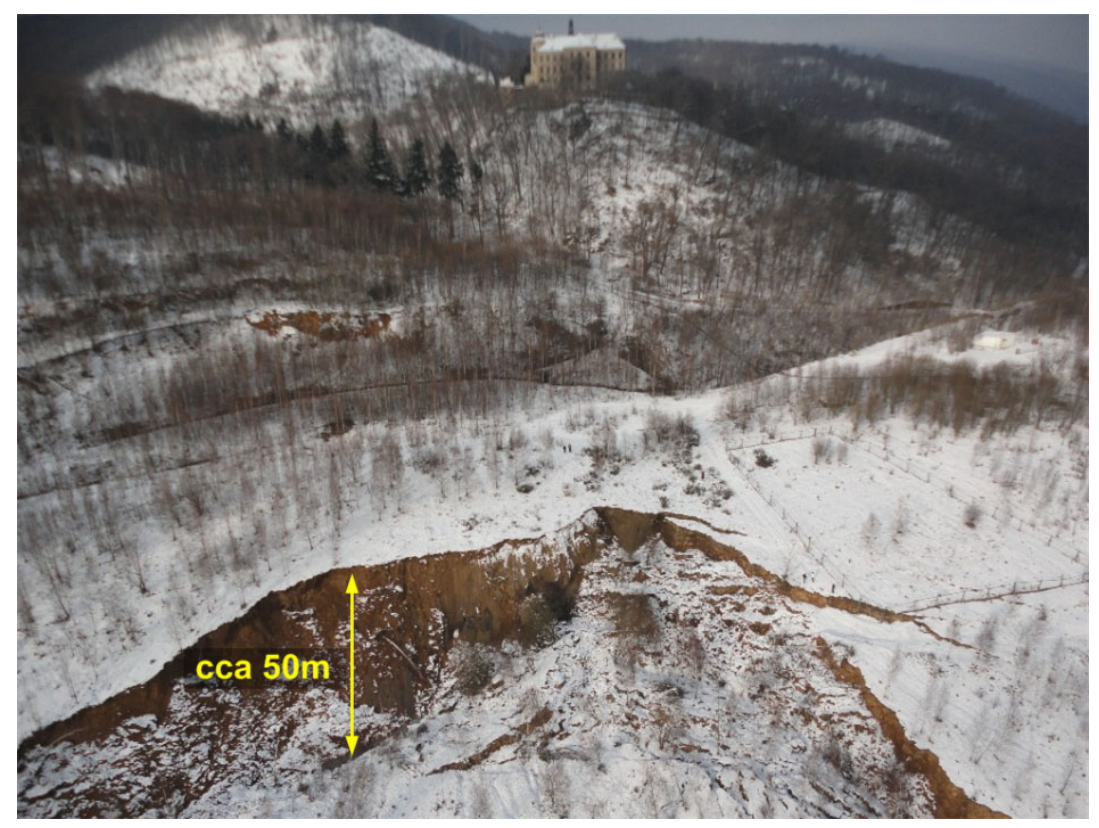

Fig. 7. Landslides at the pillar protecting the castle [11]

So far we have processed the aerial images from the year 1953 and 2008 that gave us precise DSM's of the whole area ${ }^{1}$ :

- DSM_1953 - derived from the aerial photographs - year 1953,

- DSM_2008 - derived from the aerial photographs - year 2008.

We are able to compute the landscape change in this area, and to localize the potential landslides from the DTM analysis. On Fig. 9 the boundary between the original (unchanged) georelief and the georelief that has been affected by the coal mining activity is delineated. The boundary was derived based on the differences analysis of DSM_1953 and DSM_2008 (Fig. 8) and it represents the upper pillar boundary.

The area of Jezerrí castle Hot Spot is fully covered by a series of historical mapping. These maps will be used to analyze the land-use change during the period of

\footnotetext{
${ }^{1}$ Similar naming of DTM's and DSM's is used in the rest of this paper.
} 
almost 200 years. The analysis will include maps of the $1^{\text {st }}, 2^{\text {nd }}$ and $3^{\text {rd }}$ Military Survey, Stabile Cadaster maps and historical aerial.

\subsection{Lake Most Analysis}

The analysis of Lake Most is focused on the dramatic georelief change, when a town was under-mined and then changed into a lake. The whole analysis is based on DSM's produced from aerial images and DTM's derived from elevation data contained in current and historical maps.

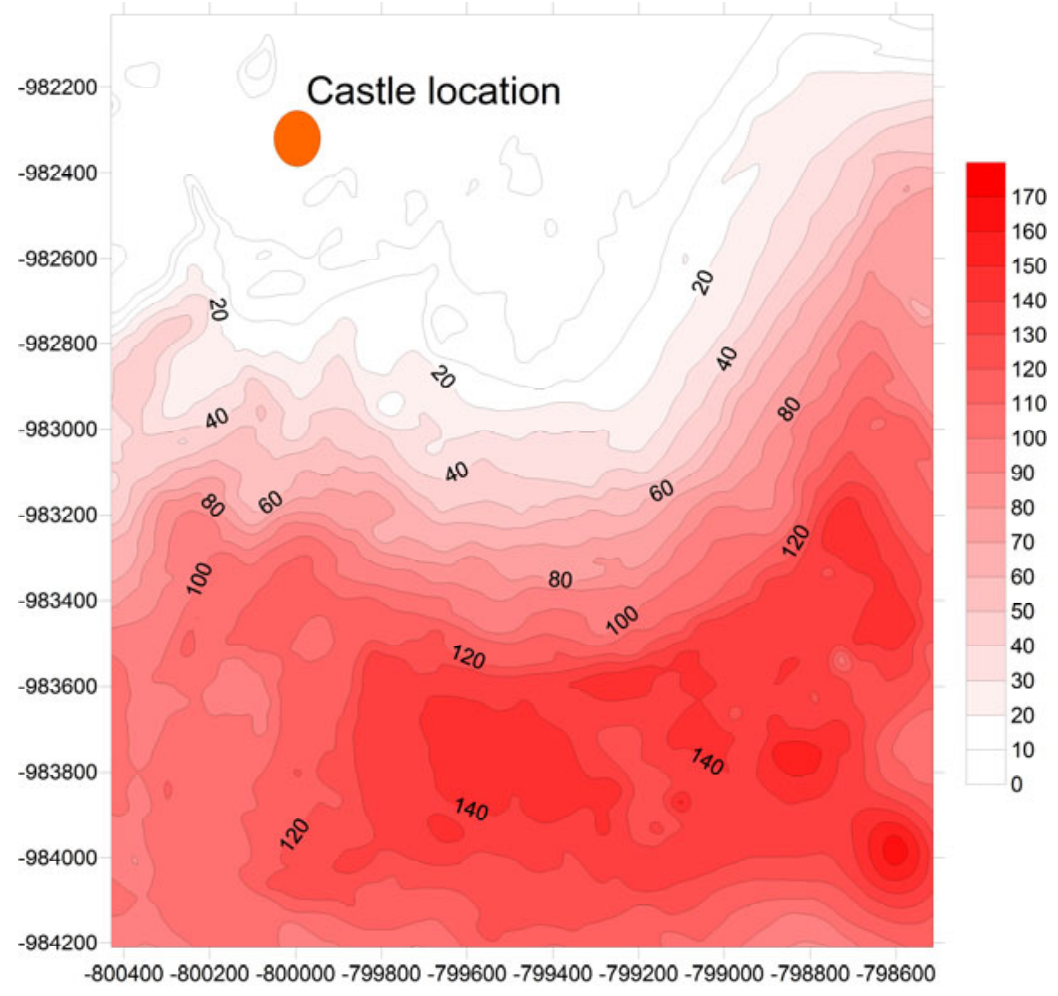

Fig. 8. Differences of Digital Surface Models created from the aerial photographs (Castle Jezeří Hot Spot) - years 1953 and 2008

Processing of the historical aerial images of this area was problematic, because the shape of the landscape has changed a lot during the past 60 years. As the source of elevation were in this case used the contour lines derived from the maps of the $3^{\text {rd }}$ Military survey. 


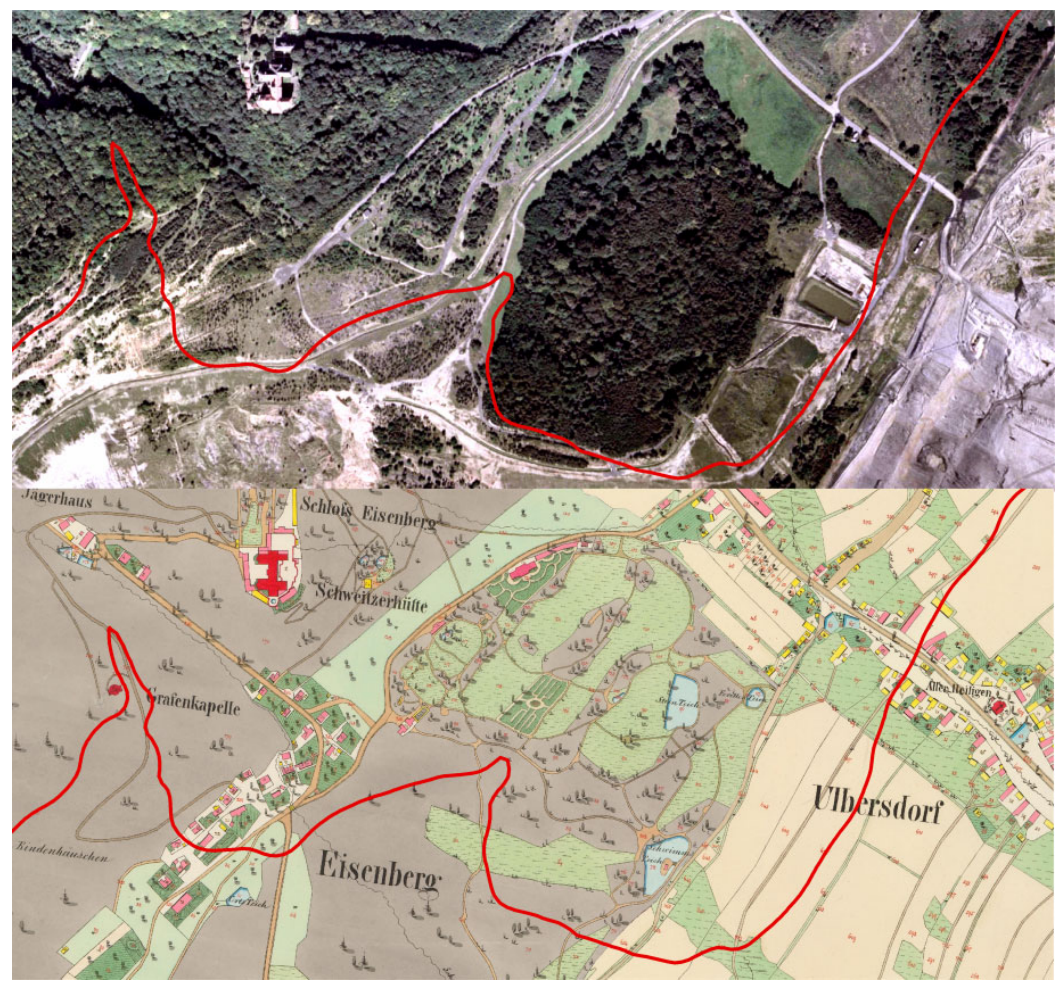

Fig. 9. Line delineating the boundary between the changed and unchanged georelief (Castle Jezeøí Hot Spot)

The analysis results have shown that the contour lines of the $3^{\text {rd }}$ Military survey are not detailed enough. In our future work they will be replaced by contour lines digitized from derived digital state-map 1:5000 from corresponding time periods. This will even help us to reconstruct the relief in different time periods of the coal mining activity.

The analysis results are representing the total georelief change between the years 1953 and 2008 (Fig. 10). Huge amount of material has been removed (positive values) from the area, but a lot of material was also stored in the deoposits (negative values).

On Fig. 11 is presented visualization of DSM's from years 1953 and 2008 derived from aerial photographs, including two elevation profiles (visualized on Fig. 12 and Fig. 13). The hillshade analysis is used to make the visualization more readable.

The future scope of this Hot Spot analysis should be the georelief reconstruction in different time periods focused on the final state of over-flooded coal mine. 


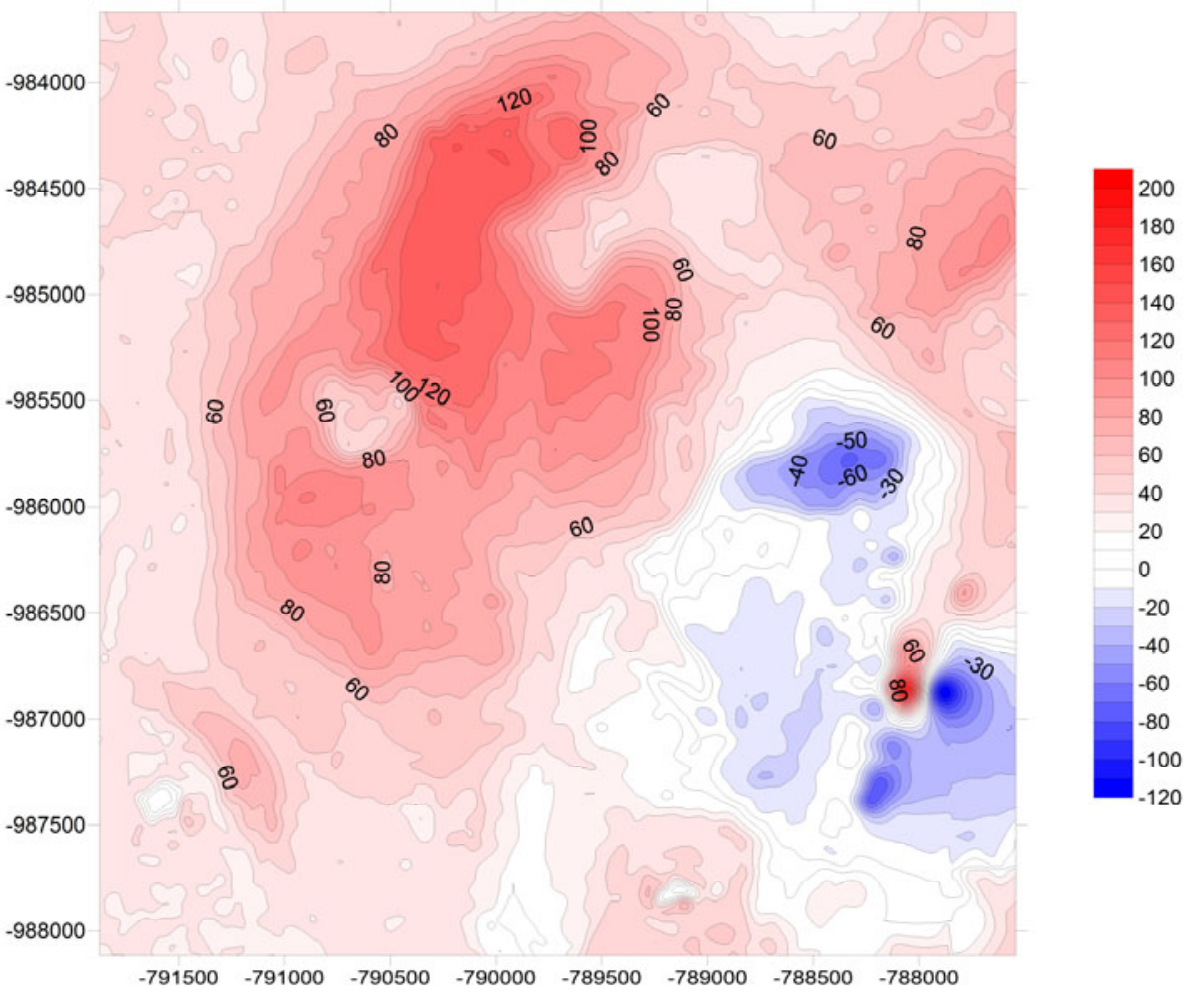

Fig. 10. Differences of Digital Surface Models created from the aerial photographs (Lake Most Hot Spot) - years 1953 and 2008

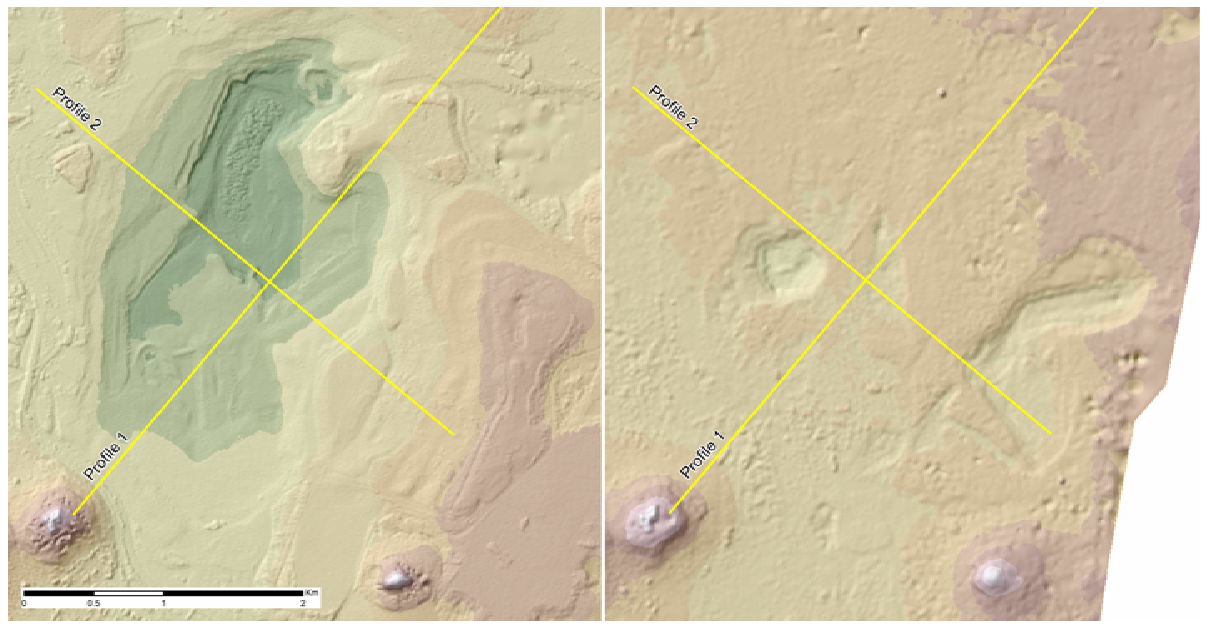

Fig. 11. Landscape change changes within the Lake Most Hot Spot. Left - year 2008. Right year 1953. Lines are delineating Profile 1 and Profile 2. 


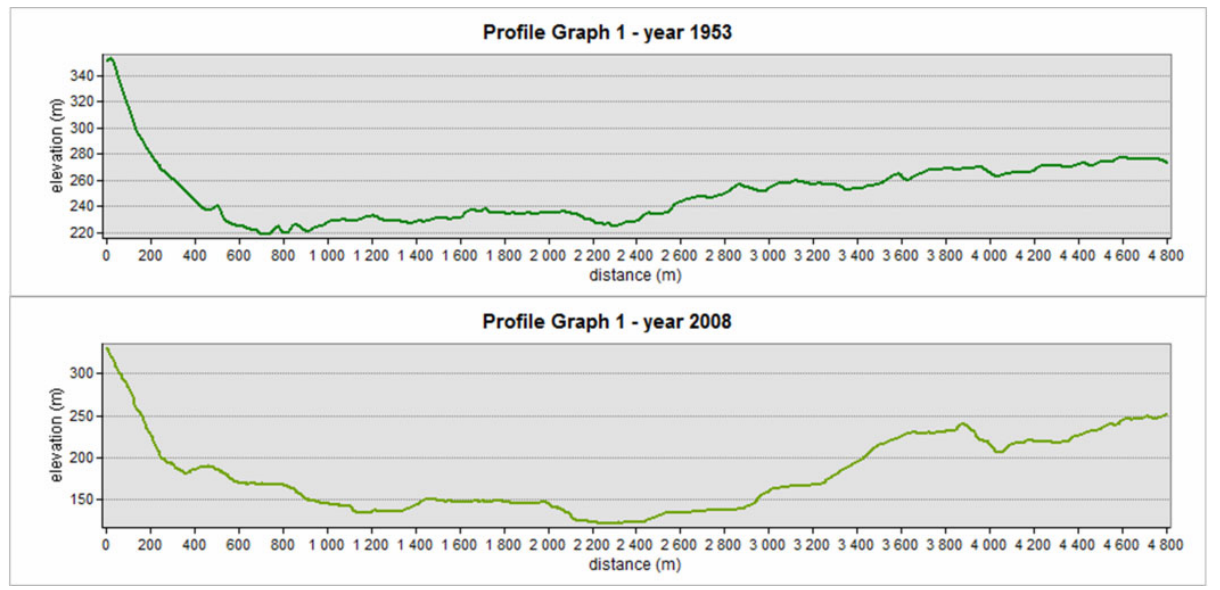

Fig. 12. Elevation profiles of Profile 1

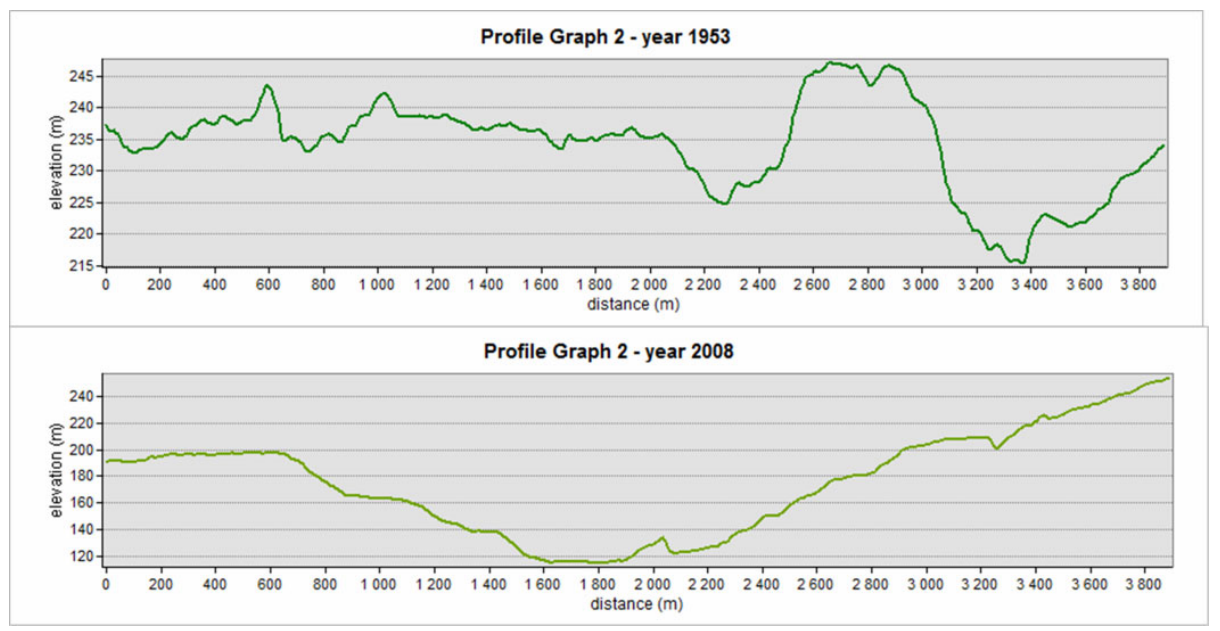

Fig. 13. Elevation profiles of Profile 2

\subsection{The Open-Cast Mine Bílina Analysis}

One of the tasks of this project is to evaluate the material amount that was mined from the selected areas or transported into the dump (deposit). The material amount is in this case equal to the volume of the upper and lower surface difference. Here we get the so called Positive Volume (Cut) and the Negative Volume (Fill). The cut portion is the volume between the upper and lower surface when the upper surface is above the lower surface. The fill portion is the volume between the upper and lower surfaces when the upper surface is below the lower surface (see Fig. 14).

The selected area (see Fig. 6) covers the main part of the open-cast mine Bílina. The historical aerial photographs from the year 1938 do not cover the whole area of the coal mine, therefore the DTM derived from the $3^{\text {rd }}$ Military survey map contours 


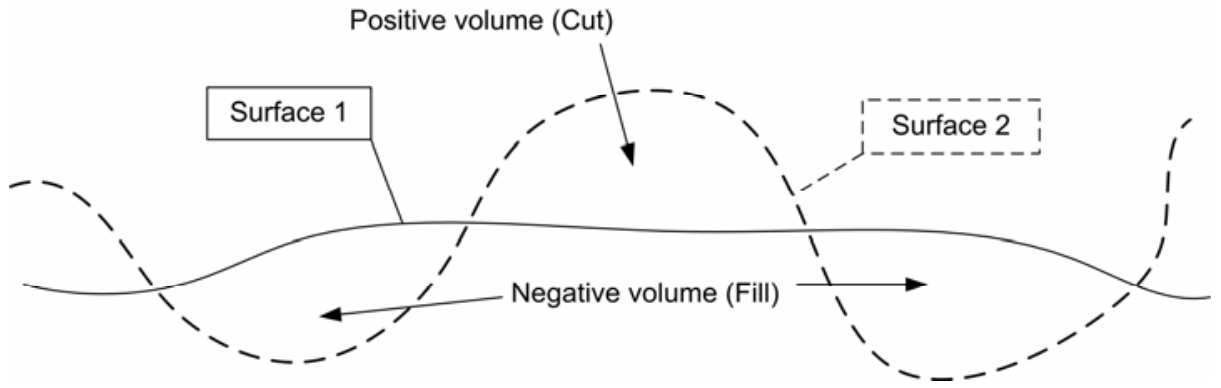

Fig. 14. Principle of volumetric analysis

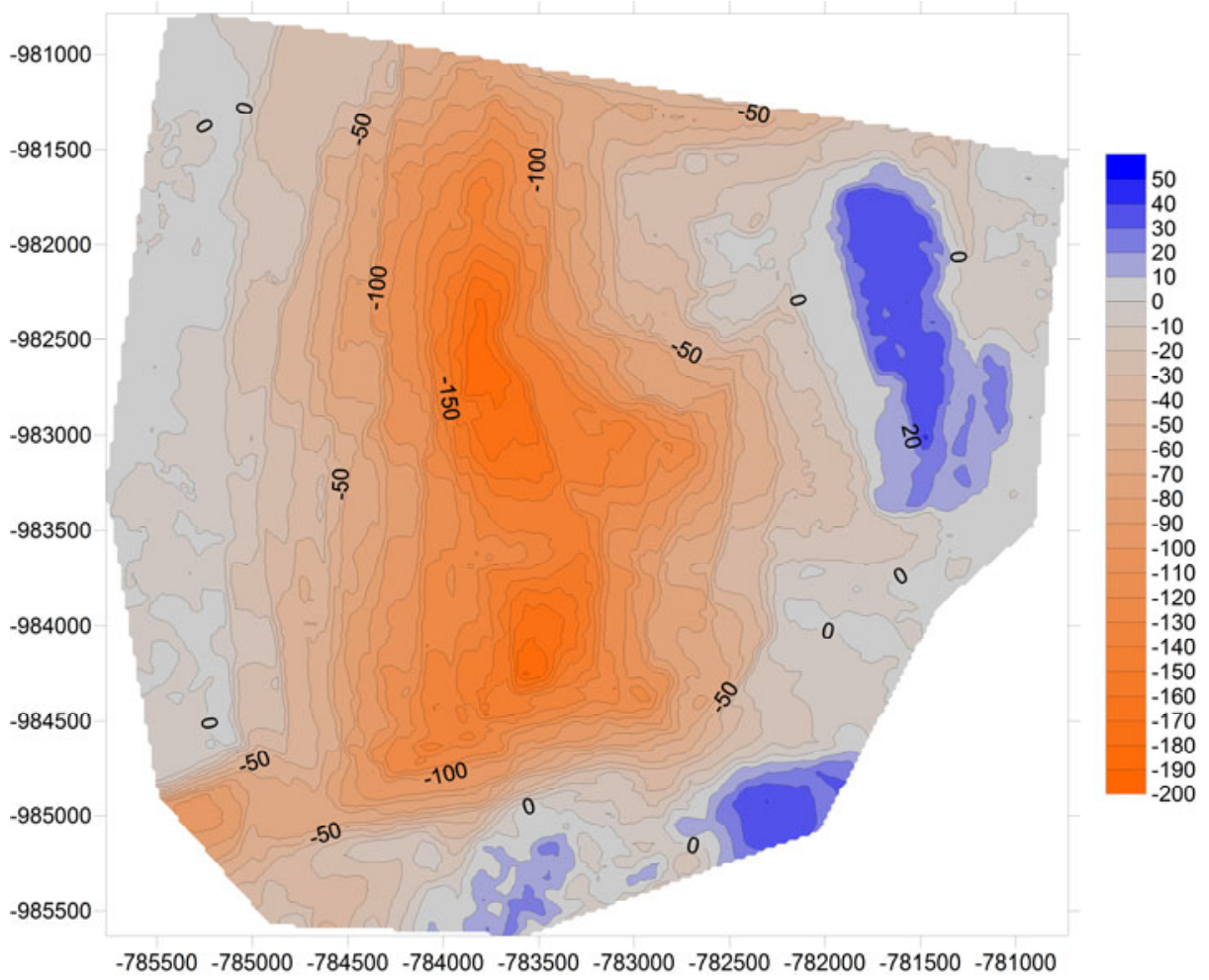

Fig. 15. Detailed difference grid of Digital Terrain Model - year 1936 and Digital Surface Model - year 1995

will be used for the volumetric analysis. The volume calculation from DTM_1936 would be proximate, as the DTM was interpolated from hand-vectorized contour lines.

The total Positive Volume (Cut) of the area is $44363951 \mathrm{~m} 3$ and the Negative Volume (Fill) is $930015080 \mathrm{~m}^{3}$. One railway transport wagon can store up to $75 \mathrm{~m}^{3}$ of material - this means (based on this computation) that to transport the material and 
coal from the Bílina mine (until the year 1995) could be used ca 12400200 wagons. Detailed difference grid of DTM_1936 and DSM_1995 is shown on Fig. 15. Visualization of the area is presented on Fig. 16 and Fig. 17.

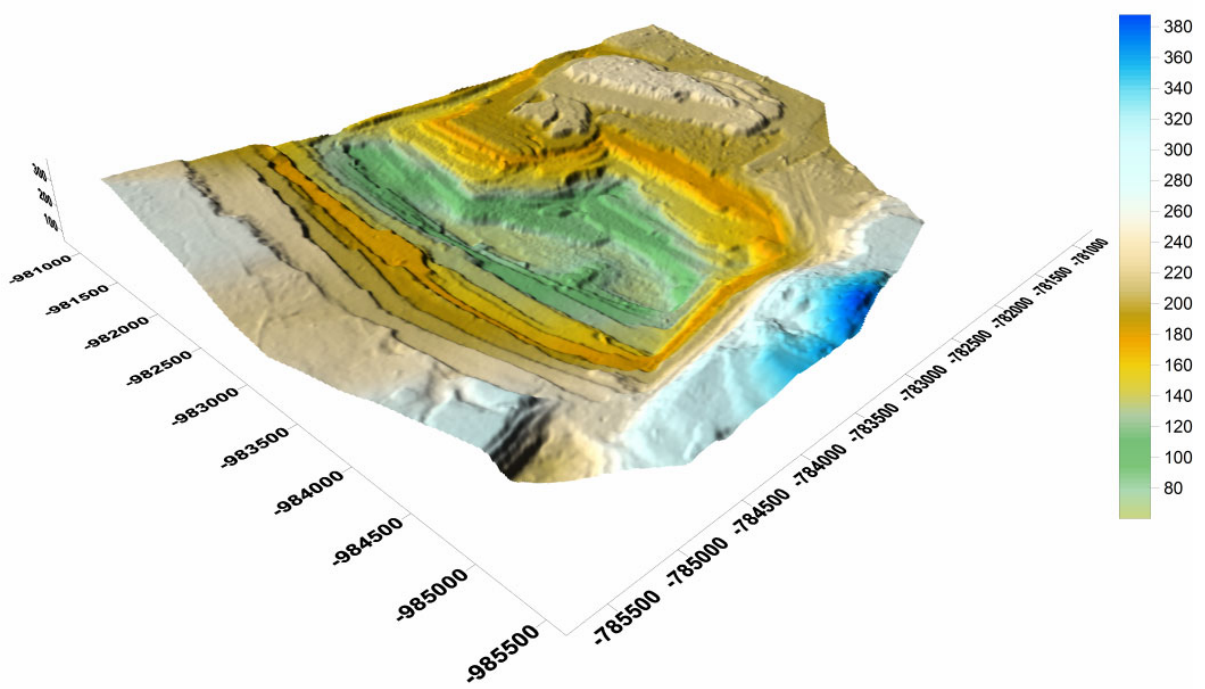

Fig. 16. Digital Surface Model of the open-cast mine Bílina - year 1995

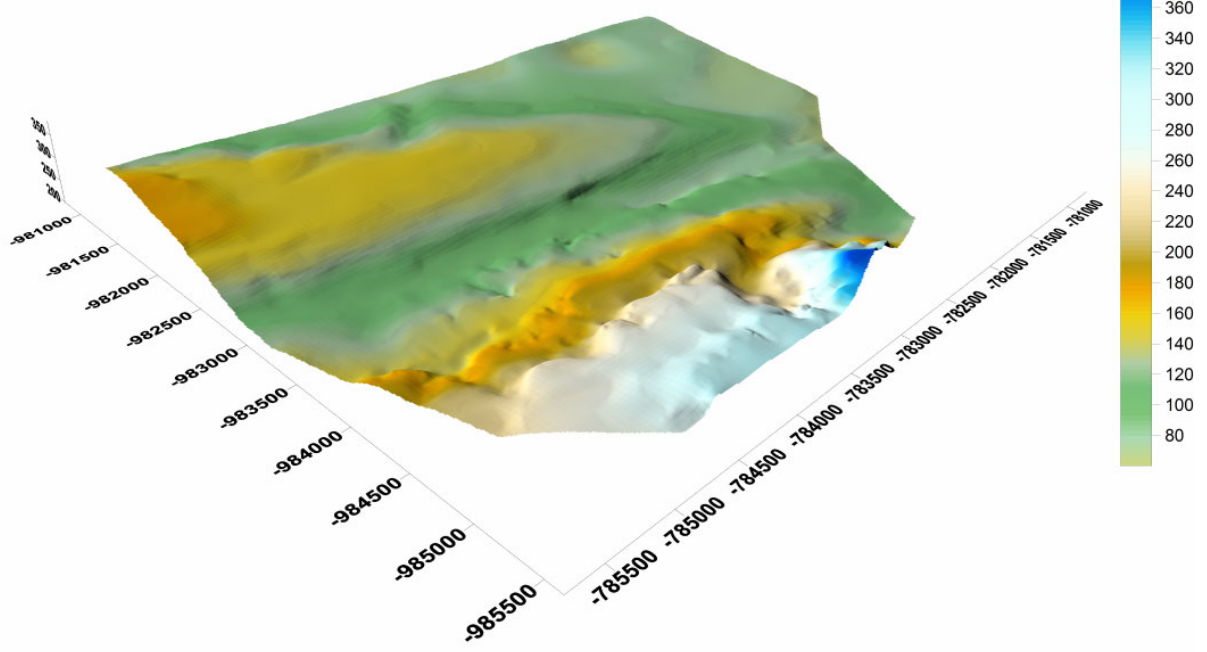

Fig. 17. Digital Terrain Model of former landscape of open-cast mine Bílina - year 1936 


\section{Conclusion}

In this paper are presented the possibilities for reconstruction and analysis of irreversibly changed georelief, using aerial images and old maps.

The maps of the $3^{\text {rd }}$ Military Survey are used as a source of elevation data in areas with a large change of the landscape and the maps of Stabile Cadaster (1:2880) are used for the landscape development analysis. The $3^{\text {rd }}$ Military Survey maps are georeferenced using a spline transformation (rubber sheeting) with a huge number of identical points - 150 to 250 per map sheet. The Stabile Cadastre maps are due to it's scale transformed using approx 30 identical points per maps sheet. This transformation method provides for both map sources sufficient accuracy for the purpose of this project. A Digital Terrain Model (DTM) was interpolated from the hand-vectorized contour lines of the $3^{\text {rd }}$ Military maps.

Within the area of the Basin of Most were chosen three Hot Spots - areas with landscape degraded by coal mining. Each of these Hot Spots has its significant structure, usage, problems and vision.

The Hot Spot Castle Jezeři is one of the biggest castles in the Czech Republic. Due to the surrounding active coal mining activity is this part of national cultural heritage endangered by geological instability and huge landslides in the castle surroundings. Within this paper the boundary between the changed and unchanged part of georelief, creating a security pillar preventing the castle from sliding down to the coal-mine was delimitated. The Digital Surface Models (DSM's) were derived from aerial photographs from the year 1953 and 2008. With these data we may perform a difference analysis which shows the total georelief change in this Hot Spots area. For the precise landslide analysis (and other possible relief movements) are required aerial photographs from the current time period, which will be available during the year 2012 .

The Hot Spot Lake Most is an example of hydric recultivation - a former coal mine is turned into a lake. The interesting fact about this Hot Spot is that in 1970' there used to be the royal town Most (25 000 inhabitants), but the huge brown-coal layers located not very deep under the Earth surface led to the destruction of the town. The landscape in this area has changed many times during the active mining. The aim of this analysis is to show the georelief evolution during this period, focused on the area of the new lake and its surroundings. From the results presented in this paper we may see that a lot of material has been stored in outer deposits around the former coal mine. The analysis results have also shown that the usage of elevation data obtained from the $3^{\text {rd }}$ Military Survey Maps do not give the results of required preciseness. For our future work we will use digital state-map 1:5000 covering the whole Hot Spot area with precise elevation data.

The Hot Spot Open-cast mine Bílina is one of the biggest active open-cast mines in this region. The analysis within this Hot Spot is focused on volumetric analysis of material that has been mined from the coal-mine area and stored in the outer deposits. Within this paper for computation of the volumetric I have used the elevation data from the 3rd Military Survey maps and DSM which is derived from the 1995 aerial photographs. The total amount of material mined in this area in the period 1936 1995 is $930015080 \mathrm{~m}^{3}$. Precise computations for the whole Hot Spot area may be found in [9] and [13]. 


\section{References}

1. Základní, Č.U.Z.K.: báze geografických dat ZABAGED ® [online]. [cit 2010-20-10], http : / / www . cuzk. cz / Dokument . aspx? PRARESKOD=998\&MENUID =0\& AKCE $=$ DOC $: 30-Z U \_Z A B A G E D$

2. ESRI ArcGIS Desktop 9.3 Help [online]. [cit 2010-20-10], http://webhelp.esri.com/arcgisdesktop/9.3/

3. Ecological Center Most: Black Triangle [online]. [cit. 2011-13-4], http: // www. ecmost.cz/ver_cz/aktualni_sdeleni/cerny_trojuhelnik.htm

4. Foto Mapy, Pohled na město Most [online]. [cit. 2011-13-4], http: / / foto.mapy.cz/original?id=14170

5. Jenny, B., Weber, A.: Map Analyst [online]. [cit 2011-15-4], http: / /mapanalyst. cartography.ch/

6. Mitas, L., Mitasova, H.: General variational approach to the interpolation problem. Computers and Mathematics with Applications 16, 983-992 (1988)

7. Mitas, L., Mitasova, H.: Interpolation by regularized spline with tension: I. Theory and implementation. Mathematical Geology 25, 641-655 (1993)

8. Neteler, M.: Open Source GIS: a GRASS GIS approach. Kluwer Academic Publishers, USA (2004) ISBN: 1-4020-8064-6

9. Pacina, J., Weiss, L.: Georelief reconstruction and analysis based on historical maps and aerial photographs. In: Proceedings of Symposium GIS Ostrava 2011, VSB - Technical University of Ostrava (2011) ISBN: 978-80-248-2366-9

10. Palivový kombinát Ústí, Napouštění Jezera Most [online]. [cit 2011-15-14], http : / / www.pku.cz/pku/site.php? location=5\&type=napousteni_most

11. Sesuv půdy pod zámkem Jezeř́ [online]. [cit 2011-15-14], http : / / www . koukej . com

12. Štýs, S.: The Region of Most - A New Born Landscape, Ecoconsult Pons Most. CZ (2000)

13. Weiss, L.: Spatio-temporally analysis of georelief changes in Bílina region caused by the coal-mining activity. Faculty of Environment, J. E. Purkyně University. Diploma thesis (2011) 